\title{
AN UNUSUAL ATTACK PATTERN OF SCOLYTUS MULTISTRIATUS BEETLES IN CHINESE ELM
}

\author{
by Pavel Švihra
}

\begin{abstract}
In autumn, some Chinese elm (UImus parvifolia Marsham) trees, especially those with large seed crops, attract Scolytus multistriatus beetles. The beetles land on a single tree in masses and attempt to penetrate the inner bark. The tree responds with a copious flow of sticky sap that kills beetles at entrances or repels them. As the sap flow increases, Scolytus beetles aggregate on the tree in even larger numbers and continue to excavate very short, erratic, and shallow tunnels in the outer bark. The basal to mid-bole section was attacked with highest density (17 to 18 tunnels per $\mathrm{dm}^{2}$, with a male-to-female ratio of $\left.1: 8.7\right)$. Perhaps due to a high concentration of host volatiles and insect-produced attractants, S. multistriatus beetles shifted their attack to adjacent elms. However, the beetles avoided penetrating the inner bark of these trees and excavated only shallow tunnels in the outer bark. The beetles also showed a preference for tunneling into the basal to mid-bole section, but high mortality was observed (36.3\% to $40.7 \%$, with a male-tofemale ratio ranging from $1: 3.8$ to $1: 4.3$ ). The number of female beetles and number of feeding scars in the crotches of small twigs were dependent on the number of females in the stem and branches $(P \geq 0.001)$.
\end{abstract}

The behavior of the smaller European elm bark beetle, Scolytus multistriatus (Marsham), vector of the Dutch elm disease (DED) fungus Ophiostoma (Ceratocystis) ulmi (Buism.) C. Moreu, is fairly well understood (Middleton et al. 1935): Adult beetles emerge in the early spring from overwintering broodwood and either disperse to feed in the crotches of small elm twigs before breeding or directly search for suitable elm wood in which to breed. Their feeding in the twigs during maturation leaves distinctive injuries that rapidly close if the beetles are not coated with fungal spores of $O$. ulmi. However, if contaminated beetles transmit spores by abrasion onto the walls of feeding injuries, the twig, branch, or whole tree may die. Feeding in twigs lasts a few days, after which beetles reemerge and fly to locate suitable elm material in which to breed. The females bore through the bark and cambium into the phloem-xylem; each constructs a single engraved maternal gallery oriented parallel to the wood grain and lays eggs singly along the gal- lery walls. During this time, both females and males may also inoculate the broodwood with DED fungus. Larvae hatch within a few days and begin to form their own galleries that radiate perpendicularly from the egg gallery. At the end of the tunnels, larvae excavate pupal cells into the bark and sapwood. During pupation, sticky spores of $O$. ulmi grow through the pupal cell walls. Pupae transform into adults that emerge with fungal spores adhering to their bodies. New beetle and DED fungus life cycles begin. In California, 2 generations per year are common (Middleton et al. 1935; Brown 1965; Brown and Eads 1966; Peacock 1975; Švihra 1980; Lanier 1981).

\section{Observations on Response of Chinese Elm to S. multistriatus Attack in Autumn}

On September 5, 1996, a homeowner in Los Gatos, Santa Clara County, California, observed a heavily bleeding Chinese elm (U/mus parvifolia) near his house. The next day, an arborist with Corporate and Commercial Services, Professional Tree Care Division, San Jose, associated the bleeding with S. multistriatus attack and found another severely bleeding elm about a block away with similar symptoms (Figure 1). On the bark surface of both trees, some beetles were found moving rapidly in circles up and down the stem while others bored into the bark. The trees responded to the attack with heavy sap flow from the stems and major limbs (Figure 2). Tunneling in the bark of 7 adjacent elms in the same area had not resulted in copious sap exudation.

On September 10, 1996, a crew removed two heavily bleeding elms. The arborist observed a completely different situation on these elms: They still showed copious flow of sap, but no beetles were landing on them. Dead adult beetles glued to the bark surface or trapped in tunnels grooved into the bark were the sole evidence of a previous S. multistriatus attack (Figure 1). Similarly, 


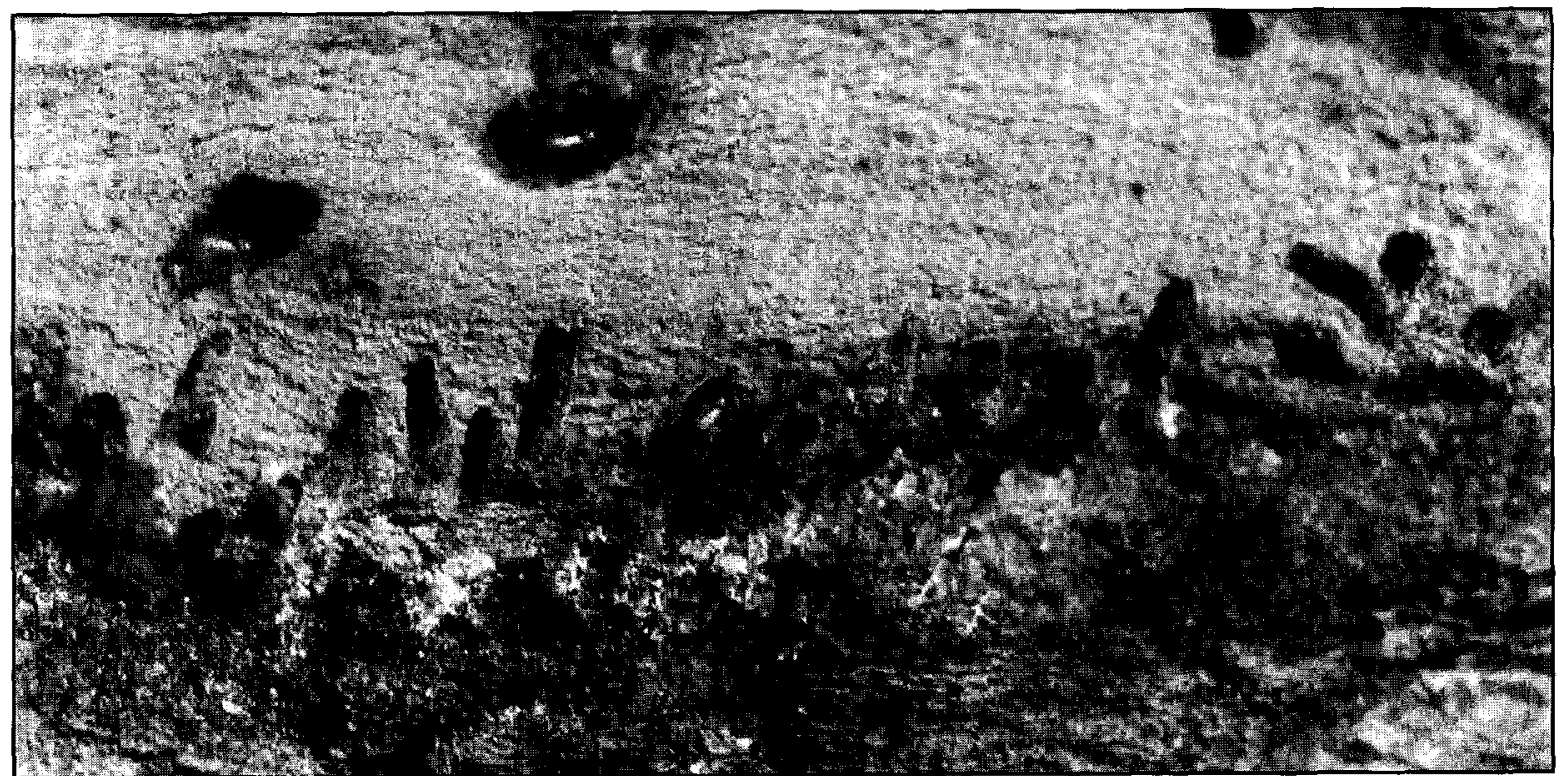

Figure 1. An unusual pattern of tunnel initiation by S. multistriatus in Chinese elm. Some beetles bored directly into the inner bark and then died, while others excavated shallow tunnels and died there. It could not be determined whether dead adults glued on the bark surface died after they vacated tunnels or simply landed in sticky sap.

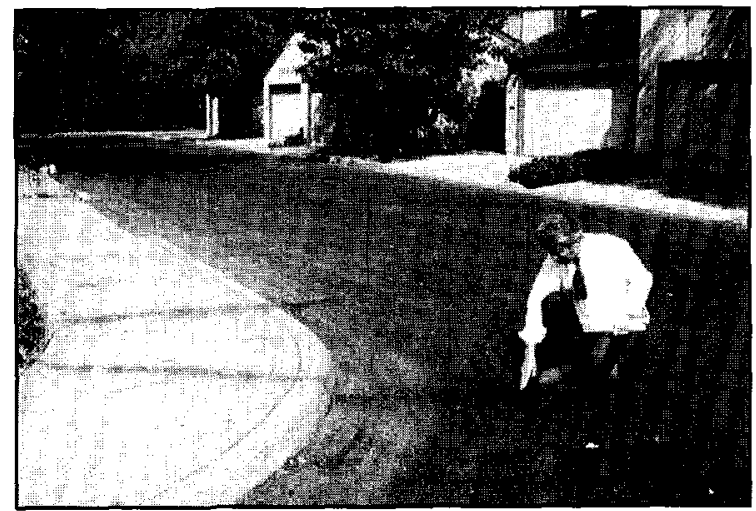

Figure 2. Traces of sap on the pavement from Chinese elm at Almond Hill Court (photographed 20 days after its removal). The radiating rays of stain on the pavement indicate that, besides the stem, branches were also heavily bleeding.

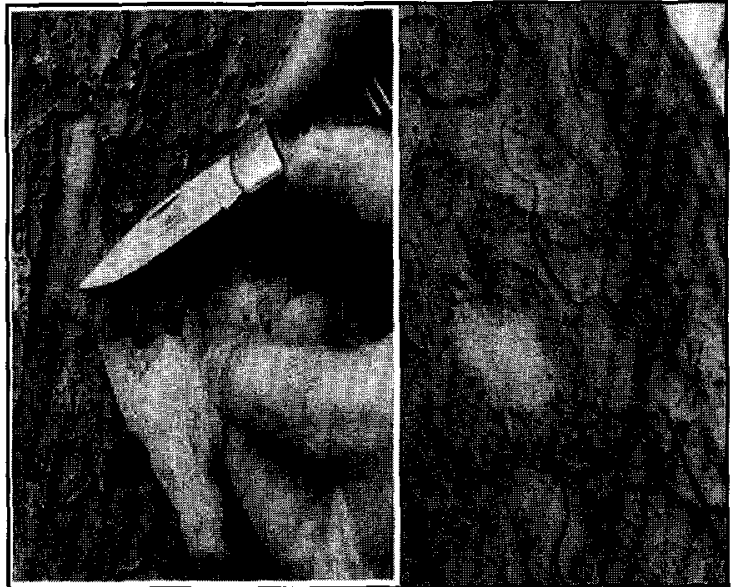

Figure 3. S. multistriatus attack pattern in initial stage is revealed, which differs slightly from the heavily attacked fluxing tree. Adults bored very shallow tunnels (burrows), avoiding inner bark from where seeping sap stained tunnel boundaries. 
in 7 elms with incipient infestations, there were no signs of living beetles-only shallow tunnels in the bark and stained blotches around them but without sap exudation (Figure 3).

Between September 30 and October 1996, the Charter Oaks Townhouse Association site was mapped and analyzed (Figure 4). Of 35 Chinese elms (27 years old), only 2 sustained attacks exhibiting copious sap flow. The host resisted these attacks with copious sap flow (Figure 2) that temporarily increased beetle aggregation, causing overcrowding, and the attack of beetles shifted to adjacent hosts where it terminated.

Examination of these elms showed apparently healthy growth but with heavy seed set at the time of attack and without dead branches that could serve as broodwood. House-to-house interviews of residents revealed that none kept or used elm firewood. About $1.6 \mathrm{~km}(1 \mathrm{mi})$ from the attacked trees, Siberian elms (U. pumila) in poor health (Figure 4) exhibited many dead branches with $S$. multistriatus exit holes and galleries beneath the bark. Two additional American/English elm street and park plantings, with a few dead and dying branches, were found 3.2 to $4.8 \mathrm{~km} \mathrm{(2}$ to $3 \mathrm{mi}$ ) away from the site.

Many arborists observed similar responses of Chinese elms to $S$. multistriatus attack in the autumn. Routinely, such trees have been promptly removed and no data about beetle spatial and temporal attack patterns were obtained. Thus, the present study was initiated 1) to determine whether a similar attack behavior in Chinese elms occurs at other sites in the greater San Francisco Bay Area, 2) to quantify the mortality and spatial distribution of attacking beetles, and 3) to determine if beetle progeny is produced.

\section{Methods}

Survey of Chinese elms for S. multistriatus attack in the San Francisco Bay area. From October to November 1996, Chinese elms planted as street trees or in parks were surveyed to locate $S$. multistriatus attacks in Santa Rosa, Rohnert Park, Sebastopol, Novato, San Rafael, Richmond, Berkeley, Lafayette, Pleasant Hill, Walnut Creek, Concord, Antioch, Santa Clara, San Jose, Palo Alto, and Woodside. More than 20 Chinese elms planted in the vicinity of other elm species were checked in each city. The survey covered an area of 100 longitude $\times 40$ latitude miles. The stem of each tree was checked for the dark brown to black beetle tunnels that are strikingly visible on the Chinese elm's light brown and flaky bark (Figure 3).

Analysis of S. multistriatus attack, mortality, and behavior in Chinese elm showing copious sap exudation. Six sections $90 \mathrm{~cm}(3 \mathrm{ft})$

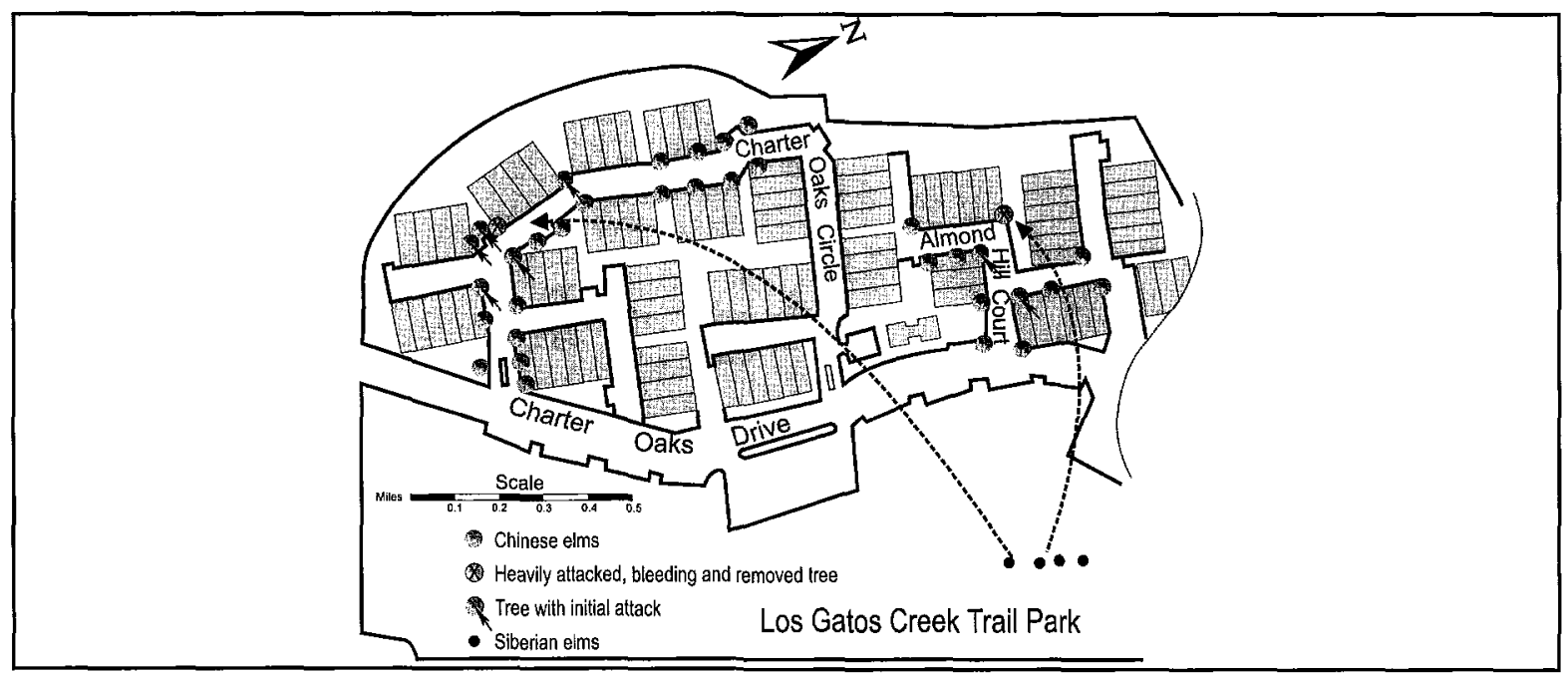

Figure 4. Distribution of elms attacked by S. multistriatus at Charter Oaks. The attack began September 5. 
in length were marked with a grease pencil and cut from the removed Chinese elm on September 10, 1996, in the following order: the 1st section taken from near the base, the 2nd at mid-stem, and the 3rd at the top of the stem below limb forking. An additional section was removed from the middle of each of the 3 major limbs. On October 15, 1996, all 6 sections were transported to the University of California at Berkeley for laboratory analysis of each log section, as follows:

1. precise measurement of circumference and length of each log section to determine its surface area

2. removal with forceps of dead beetles trapped in sticky sap on the bark surface; these were placed in vials of hexane for further analysis

3. dissection and removal with scalpel and forceps of all beetles that bored and died in tunnels; these were preserved as above

4. total count of boring tunnels on the bark surface by marking each tunnel with a grease pencil

5. de-barking of each section with a chisel to determine the number of beetle galleries through the phloem and into the xylem, and to investigate egg gallery construction as well as development of progeny beneath the bark

6. counts of beetles and determination of their sex for each sampling category (on the bark surface; in the tunnel) for each section.

Sampling for spatial distribution of $\mathbf{S}$. multistriatus attack in standing elms. Two distinctive types of $S$. multistriatus attacks were considered for sampling of standing trees: 1) those found on the main stem and branches, and 2) those found in crotches of small twigs.

To evaluate 7 Chinese elms showing incipient attacks that terminated, the stems and branches of each tree were divided into 6 sampling levels (Figure 5) beginning at the ground and finishing with the uppermost twigs. The top and bottom of each $30-\mathrm{cm}$ ( 1 -ft)-long band on the bark surface was marked with a grease pencil as follows: the 1st sample beginning at root flare, the 2nd in the middle of the main stem, and the 3rd at the top of

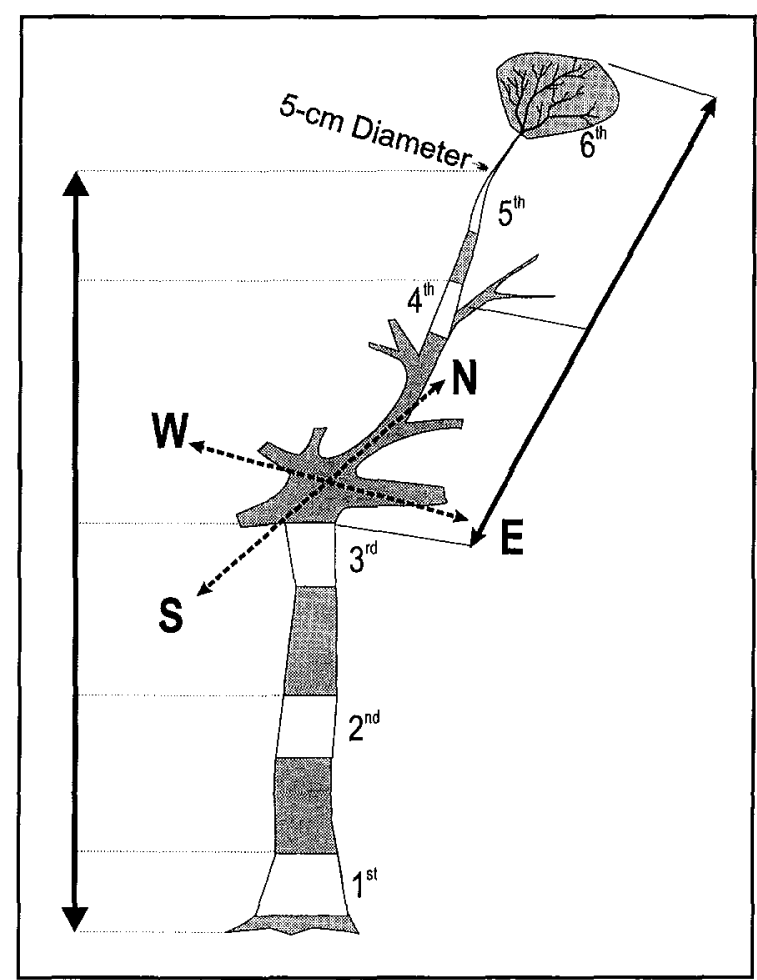

Figure 5. Vertical distribution of samples in Chinese elm with incipient infestations.

the main stem with its top line just beneath where the first limb forked. Then, 4 branches were selected according to cardinal compass directions. The length of each branch was measured with a PENTAX leveling rod (fiberglass segments, expandable to $7.5 \mathrm{~m}$ [25 ft]) from the top line of the 3rd sample band to its tip. At the midpoint of each limb, the 4th sample band was positioned and the top line of the 5th band was set where the branch became $5 \mathrm{~cm}$ (2 in.) in diameter-the smallest diameter at which $S$. multistriatus beetles normally reproduce (Švihra and Koehler 1982). The vertical distance of each band from the ground was measured with a PENTAX leveling rod and recorded. The 6th samples, consisting of $50-\mathrm{cm}$ (20-in)-long branch tips cut from each limb by a pole pruner, were used to count the feeding wounds left by beetles in the crotches of twigs. A step ladder, rope, and saddle were used to reach and analyze the bands.

Dead beetles in the tunnels were counted, and then all tunnels with and without beetles at each 
sampling interval were counted. The dead beetles were removed from the tunnels with a scalpel and forceps and stored in vials with hexane for each sample band for a determination of their sex. These numbers divided by the surface area of the band gave the attack density per $\mathrm{dm}^{2}$. The attack densities of the 4th and 5th samples were obtained by totaling the attacks on all four samples at each sampling height and for each category (tunnels occupied with dead beetles; vacant tunnels) and then dividing by the sum of their surface area.

Statistical analysis. The relationship of attack density with tree height was tested by analysis of variance (SAS Institute 1985). Because the density of attack differed widely from tree to tree, the numbers of tunnels and dead beetles were converted to a percent distribution within each tree. By this method, each tree had $100 \%$ attack. Hence, the variance within treatments became homogenous. Statistical significance was based on the transformed data to arcsin. Fisher's Protected LSD test at $P=0.05$ was used for mean separation. A nonlinear regression evaluated the regressive decline in beetle infestation level with increasing sampling height in a tree. The regression/correlation analysis evaluated the relationship between the level of infestation in the whole tree to the sex ratio and the percentage of feeding injuries.

\section{Results}

Search for $S$. multistriatus attack in Chinese elms. The survey included 41 sites representing a broad variety of microhabitats of Chinese elms planted as street trees or in parks and in different mixtures with other elm species. There was no evidence of $S$. multistriatus attack on the stems of the 673 surveyed Chinese elms.

Only nine Chinese elms in Charter Oaks appeared suitable for $S$. multistriatus attack. Ninetysix Chinese elms examined within a radius of $1.6 \mathrm{~km}$ (1 mi) from Charter Oaks were also not attacked.

Literature on $S$. multistriatus life history and habits is voluminous, but no reports of Chinese elm defense that has altered $S$. multistriatus behavior were found. Why this behavior always oc- curs in the autumn and whether host characteristics or phenology of the Chinese elm plays a central role in altering the beetle's behavioral responses need to be investigated further.

When entering winter hibernation, the native elm bark beetle (Hylurgopinus rufipes) attacks the lower bole of apparently healthy American elm trees, producing red boring dust in the bark fissures, but sap production has not been observed (Stipes and Campana 1981). Those authors present a photograph showing a tunneling pattern by overwintering adults of $H$. rufipes that is strikingly similar to that in Figure 1.

Attack pattern of S. multistriatus in Chinese elms showing copious sap exudation. The 6 sections cut from the Chinese elm consisted of $216.6 \mathrm{dm}^{2}$ of bark surface from which 2,125 beetles (about 10 dead beetles per $\mathrm{dm}^{2}$ ) were recovered. Even this high beetle-density pressure was insufficient to overcome the Chinese elm's resistance (Table 1). On average, 3.4 females (per $1 \mathrm{dm}^{2}$ of bark) penetrated through the phloem and into the xylem, but all of them died before brood galleries were constructed. The density of tunnels on the bark surface (erratically bored entries by adults that slightly grooved into bark, as shown in Figure 1) was very high (14.1 per $\left.\mathrm{dm}^{2}\right)$. With this sampling technique, it was not possible to ascertain whether a different individual bored each tunnel; nevertheless, the mortality of beetles in the tunnels was very high.

The sex ratio of dead beetles on the bark surface was about 1:1.2 (372 males, 464 females). However, in tunnels combined with penetrations into the inner bark and the xylem there were 8.6 times more females than males, for a ratio of $1: 8.6$ (134 males, 1,155 females). Such a high shift in sex ratio suggests that the females initiated the attack and released a pheromone as they penetrated into bark.

Spatial distribution of $\mathbf{S}$. multistriatus in Chinese elms adjacent to elms showing copious sap exudation. Tunnel density and mortality of adults in the adjacent elms spatially differed (Table 2). The lower stem of the tree was attacked with the highest density where $S$. multistriatus initiated 34.5 per $\mathrm{dm}^{2}$ of the tunnels, yet in most of them or on the bark surface the 
Table 1. Spatial distribution of attack density, mortality, and sex ratio of $S$. multistriatus based on counts in cut sections removed from main stem and three major branches of Chinese elm tree showing copious sap flow.

\begin{tabular}{|c|c|c|c|c|c|c|c|}
\hline Tree section & $\begin{array}{l}\text { Surface } \\
\text { area } \\
\text { in } \mathrm{dm}^{2}\end{array}$ & $\begin{array}{l}\text { No. of } \\
\text { penetrations } \\
\text { to inner bark } \\
\text { per } \mathrm{dm}^{2}\end{array}$ & $\begin{array}{l}\text { Tunnel } \\
\text { density } \\
\text { per dm² }\end{array}$ & $\begin{array}{l}\text { Dead } \\
\text { beetles in } \\
\text { tunnels per } \\
\mathrm{dm}^{2} \text { of } \\
\text { surface }\end{array}$ & $\begin{array}{l}\text { Sex ratio } \\
\text { (m:f) in } \\
\text { tunnels }\end{array}$ & $\begin{array}{l}\text { Dead } \\
\text { beetles on } \\
\text { the bark } \\
\text { per } \mathrm{dm}^{2} \text { of } \\
\text { surface }\end{array}$ & $\begin{array}{l}\text { Sex ratio } \\
(\mathrm{m}: \mathrm{f}) \text { on } \\
\text { the bark }\end{array}$ \\
\hline Lower stem & 54.8 & 4.8 & 18.3 & 10.0 & $1: 9.2$ & 7.0 & $1: 1.3$ \\
\hline Middle stem & 46.2 & 3.5 & 16.9 & 7.3 & $1: 7.6$ & 5.9 & $1: 1.3$ \\
\hline Upper stem & 39.4 & 3.1 & 14.6 & 6.4 & $1: 11.2$ & 5.2 & $1: 1.2$ \\
\hline Branch \#1 & 26.4 & 2.4 & 14.2 & 3.0 & $1: 8.4$ & 2.0 & $1: 1.2$ \\
\hline Branch \#2 & 25.2 & 2.1 & 14.1 & 3.2 & $1: 7.1$ & 2.2 & $1: 1.3$ \\
\hline Branch \#3 & 24.6 & 3.3 & 13.8 & 2.9 & $1: 9.5$ & 2.9 & $1: 1.2$ \\
\hline \multirow[t]{2}{*}{ Total } & 216.6 & $(745)$ & $(3,074)$ & $(1,289)$ & $134: 1,155$ & $(836)$ & $372: 464$ \\
\hline & & 3.4 & 14.1 & 5.9 & & & \\
\hline Mean & & 3.4 & 14.1 & 5.9 & $1: 8.6$ & 3.9 & $1: 1.2$ \\
\hline
\end{tabular}

Table 2. Mean percent spatial distribution of $S$. multistriatus tunnels, dead adults, and sex ratio based on 7 trees.

\begin{tabular}{|c|c|c|c|}
\hline \multirow[b]{2}{*}{ Band } & \multicolumn{2}{|c|}{ Mean $\%$ distribution of } & \multirow[b]{2}{*}{ Sex ratio $(m: f)$} \\
\hline & Tunnels ${ }^{x}$ & Dead beetles & \\
\hline 1 & $34.5 a^{y}$ & $36.3 \mathrm{a}$ & $1: 4.3 \mathrm{a}$ \\
\hline 2 & $39.0 \mathrm{a}$ & $40.7 a$ & $1: 3.8 \mathrm{a}$ \\
\hline 3 & $19.1 b$ & $17.1 \mathrm{~b}$ & 1:4.1 a \\
\hline 4 & $5.5 \mathrm{c}$ & $5.5 \mathrm{c}$ & $1: 3.2 \mathrm{a}$ \\
\hline 5 & $2.0 \mathrm{c}$ & $0.4 d$ & $N^{2}$ \\
\hline
\end{tabular}

"Both number of tunnels and number of dead beetles were expressed per $\mathrm{dm}^{2}$ of surface area, then as a percent distribution by section. Statistical analysis performed with arcsin of square root of proportion transformed data. yMeans within a column with no letters in common are significantly different by Fisher's Protected LSD test at $P=0.05$.

${ }^{2}$ Only females attacked this section in a very low attack density.

beetles also died ( 36.3 per $\mathrm{dm}^{2}$ ). As the attack extended from lower to upper stem, the density of tunnels significantly decreased (about twofold), in spite of bark with more flakes, cracks, and fissures in the area where the branches fork from the stem. The spatial pattern of tunnel density in the stems and branches is a nonlinear relationship (Figure 6). Tunnel density was highest in the lower stem and tapered abruptly toward the top and branches. However, the sex ratio was not affected by increased tree height (Table 2). Three to four more females initiated tunnels regardless of stem height. Yet sex ratio was very closely related to density of tunnels (Figure 7). As tunnel density increased, the number of females that had arrived, initiated tunnels, and died therein increased significantly.

Beetles did not die in the burrows during feeding in small twigs. Initiation of feeding injuries in crotches of small twigs was also closely related to tunnel density (Figure 8). As tunnel density in the tree increased, the number of feeding injuries in the crotches increased significantly.

\section{Discussion}

Of 35 apparently healthy Chinese elms $S$. multistriatus, beetles selected and mass-attacked only 2 that responded with copious sap flow. Only these trees, which were $1.2 \mathrm{~km}(0.75 \mathrm{mi})$ apart, emanated odors attractive to the beetle. Data collected from 1 such tree, which was cut down, showed that adults penetrated into the inner bark and xylem in very high numbers ( 3.4 female beetles per $\mathrm{dm}^{2}$, Table 1), yet such an attack was not sufficient to overcome host resistance and permit establishment of egg galleries. Research remains to be done to explain whether this unusual host resistance is seasonally (during the autumn) or phenologically induced during seed set.

Beetles bored lateral tunnels without penetrating into the inner bark. The bark beetle host selection is a complex communication system (Stark 


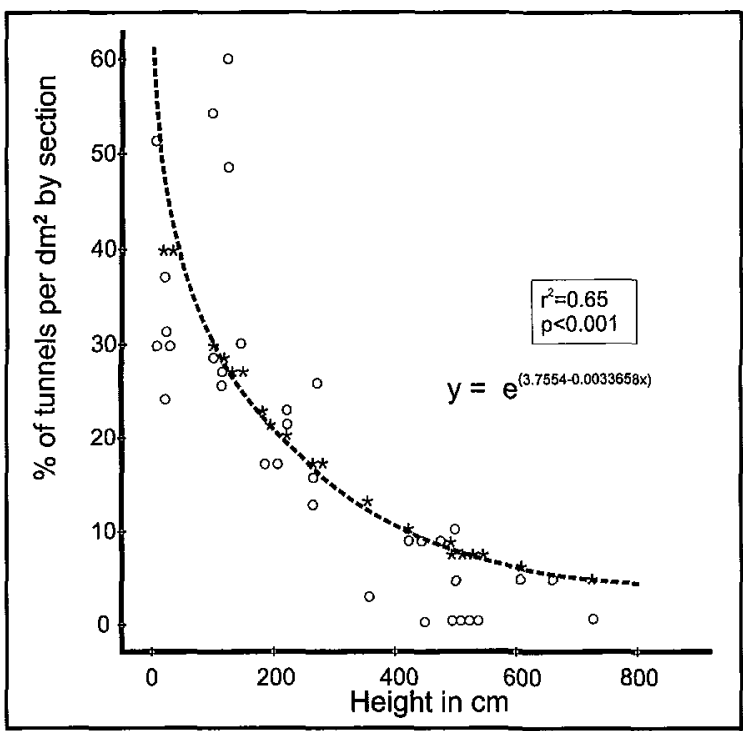

Figure 6. Within-tree spatial distribution of $S$. multistriatus tunnels in relation to increased tree height, illustrating a decrease in number of excavated tunnels with increasing height $(0=$ observed tunnels, by percentage; * = predicted tunnels, by percentage).

et al. 1985), possibly involving attractive or repellent vapors from the tree and chemical signals between beetles of the same and opposite sex. Both attacked trees responded with copious sap flow (Figure 2), which could be toxic or physically debilitating to beetles. The massive aggregation of beetles in these 2 trees continued for at least 2 days, suggesting that both host-produced attractants and insect-produced pheromones were released (Peacock et al. 1971; Borden 1974; Pearce et al. 1975; Lanier 1978). At the same time, however, their attack shifted to adjacent trees. Was it because of the "switching" phenomenon (Gara and Coster 1968) that beetles moved to attack adjacent trees? The initial attack process in adjacent trees began with females, whose numbers were closely related to tunnel density (Figure 7). Both sexes aggregated only in nearby trees and did not disperse to trees further from those with abundant sap flow.

Similar $S$. multistriatus attack behavior occurred in September 1986 in Antioch, Contra Costa County, California. A single Chinese elm with a large seed crop was heavily attacked late

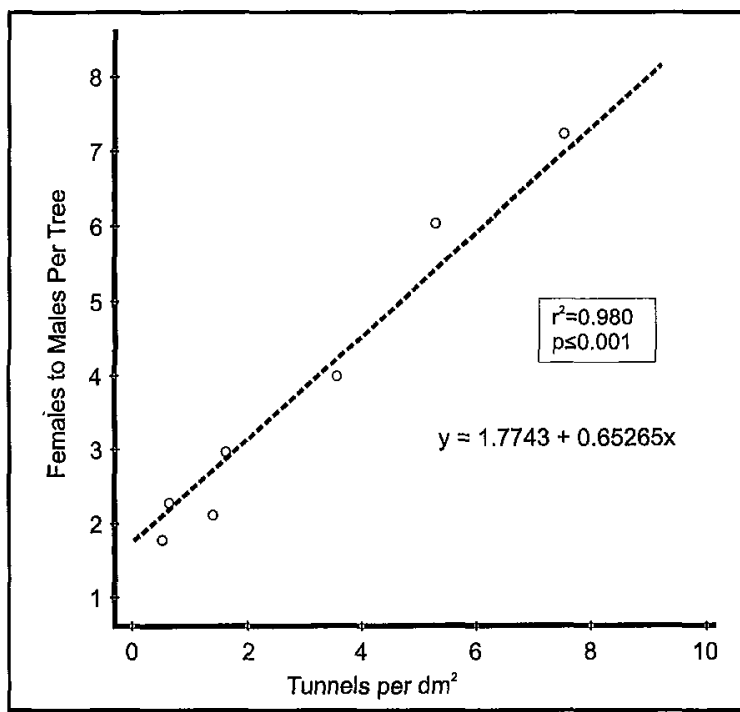

Figure 7. The correlation between S. multistriatus sex ratio and tunnel density.

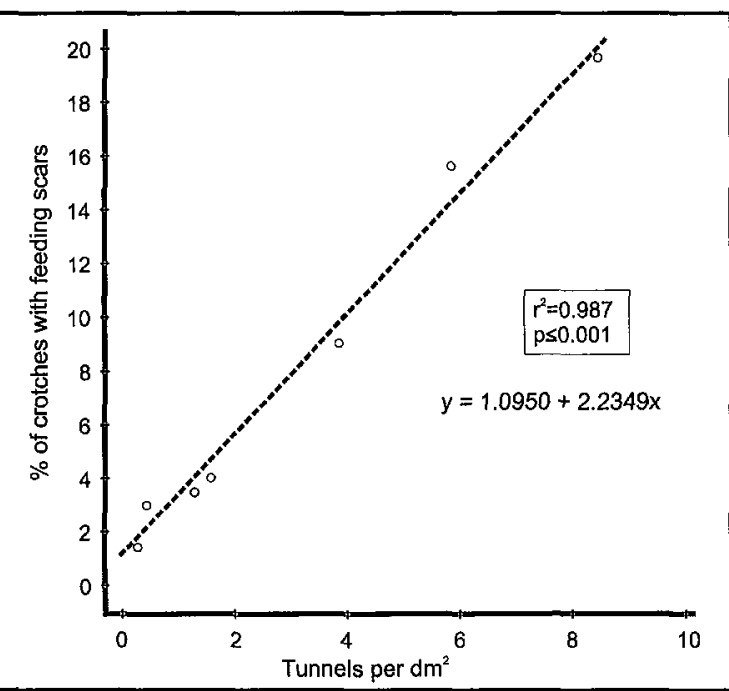

Figure 8. The correlation between S. multistriatus crotch feeding and tunnel density.

one afternoon by $S$. multistriatus beetles (at noon, there was no sign of tree bleeding; at 6:00 P.M., the main trunk was "brown with beetles and sap," the homeowner stated). Personnel from the Contra Costa County Agricultural Commissioner's office sprayed the elm with an insecticide before its removal to comply with the California State Dutch Elm Disease Eradication Program. In Palo Alto San Mateo County, on September 10, 1997 


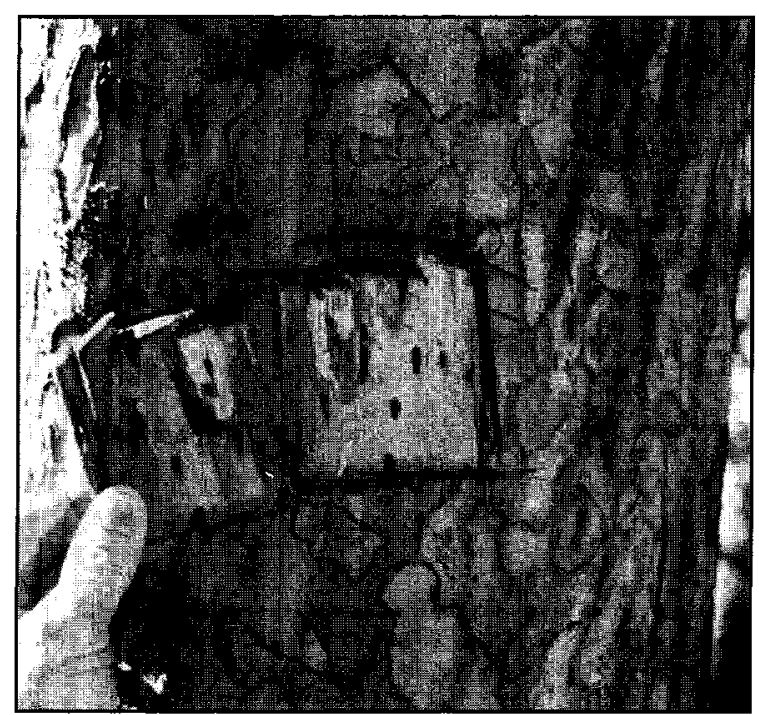

Figure 9. The beetles died after penetrating into the inner bark.

(one year after this investigation began), $S$. multistriatus beetles again were attracted to and attacked a single Chinese elm in a very similar pattern (Figure 9) yet avoided other cohorts in the vicinity.

English elm (U. procera), Siberian elm $(U$. pumila), and Chinese elm (U. parvifolia) are the most widely planted species in the state (Brown 1965; Švihra and Koehler 1981). All elm species are palatable to $S$. multistriatus (Neely 1975 , and references therein) but in California $S$. multistriatus discriminates among these hosts. When freshly cut bolts from English, Siberian, and Chinese elms were exposed as attractants (baits) to flying $S$. multistriatus beetles that emerged from a pure English elm stand, significantly more beetles responded to bolts from English elms than to Siberian elms (Švihra and Koehler 1981). In contrast, in a pure Siberian elm stand, the catches of beetles on traps baited with English and Siberian elm bolts did not differ significantly. Interestingly, the catches of $S$. multistriatus on traps baited with freshly cut Chinese elm bolts always were significantly lower than on traps with English and Siberian bolts and did not differ from catches on unbaited-empty traps. However, in southern California (Brown and Eads 1966), $S$. multistriatus beetles successfully attacked waterstressed Chinese elms in the late summer or early autumn. When these elms were irrigated, the beetle invasion terminated and some trees survived. Dissection and debarking of sections from the cut elm in the present study support Brown and Eads' (1966) finding with one exception: females in the inner bark died without additional irrigation of the tree.

Theoretically, a single female or a few pioneer beetles identify a suitable host (Peacock et al. 1971; Borden 1974; Lanier 1978) and penetrate the bark to release a population aggregation pheromone to which both sexes respond in large numbers (Wood 1972). Such production of an aggregation pheromone (Wood 1972) is supported by data in Tables 1 and 2 .

The diamond-shaped samples cut with a chisel through the bark and sapwood removed from mass-attacked and heavily sapping Chinese elm as well as those removed from 7 elms with incipient attacks in Charter Oaks were not infected with the DED fungus (T. Tidwell, personal communication). Elms appeared to be healthy during 1997.

Beetles feed randomly in elm twig crotches as they disperse in the crowns of nearby healthy elm trees (Meyer and Norris 1967; Baker and Norris 1968; Gilbert and Norris 1968). In this study, however, as the density of $S$. multistriatus tunnels increased in the stem and branches, the number of feeding injuries also increased. In locating an elm for feeding and breeding, $S$. multistriatus first feeds in crotches of small twigs of elms for maturation (Middleton et al. 1935; Wolfenbarger and Buchanan 1939) and then flies to find weakened or dying and dead eim trees (Welch 1953; Brown and Eads 1966). The point at which crotch feeding started in Chinese elms could not be determined with this sampling technique. S. multistriatus adults successfully entered the twigs of Chinese elms, but no dead beetles were found.

In California, the beetle kills and reproduces in drought-stressed elms (Brown and Eads 1966). But most commonly it reproduces in dying or dead branches or firewood that sometimes has aged for weeks. After $S$. multistriatus was discovered in California in 1951 (Armitage 1951), this expansion of its range was accompanied by changes in host species available for colonization. In Cali- 
fornia (Švihra and Volney 1983), females demonstrated a distinct preference for English and Siberian elms over Chinese elms in attacks on bolts arranged randomly in woodpiles. If they were forced to attack Chinese elm in the laboratory, most of them died before establishing egg galleries.

Host odors have been shown to be important cues for host recognition by $S$. multistriatus (Martin 1936; Meyer and Norris 1967; Baker and Norris 1968; Gilbert and Norris 1968; Blight et al. 1977; Śvihra and Volney 1983). Whether or not Chinese elm odors can be practically used to control S. multistriatus awaits further study.

\section{Literature Cited}

Armitage, H.M. 1951. Current insect notes. Bull. St. Calif. Dep. Agric. XL:111-118.

Baker, J.E., and D.M. Norris. 1968. Further biological and chemical aspects of host selection by Scolytus multistriatus. Ann. Entomol. Soc. Am. 60:12481255.

Berryman, A.A. 1972. Resistance of conifers to invasion by bark beetle-fungus associations. BioScience 22:598-602.

Blight, M.M., F.A. Mellon, L.J. Wadhams, and M.J. Wenham. 1977. Volatiles associated with Scolytus scolytus beetles on English elm. Experentia 33:845-846.

Borden, J.H. 1974. Aggregation pheromones in the Scolytidae, pp 135-160. In Birch, M.C. (Ed.). Pheromones. American Elsevier Publishing, New York, NY.

Brown, L.R. 1965. Seasonal development of the smaller European elm bark beetle in southern California. J. Econ. Entomol. 58:176-177.

Brown, L.R., and C.O. Eads. 1966. A technical study of insects affecting the elm tree in southern California. University of California. Bull. 821.24 pp.

Gara, R.I., and J.E. Coster. 1968. Studies on the attack behavior of the southern pine beetle. III. Sequence of tree infestation within stands. Contrib. Boyce Thompson Inst. 24:77-86.

Gilbert, B.L., and D.M. Norris. 1968. A chemical basis for bark beetle (Scolytus) distinction between host and non-host trees. J. Insect Physiol. 14:1063-1068.

Lanier, G.N. 1978. Behavior-modifying chemicals as a basis for managing bark beetles of urban importance, pp. 295-310. In Frankie, G.W., and C.S. Koehler (Eds.). Perspectives in Urban Entomology. Academic Press, New York, NY.
Lanier, G.N. 1981. Behavior-modifying chemicals in Dutch elm disease vector control, pp 371-394. In E.S. Kondo, E.S., Y. Hiratsuka, and W.B.G. Denyer (Ed.). Proceedings of the Dutch Elm Disease Symposium and Workshop. Winnipeg, Manitoba.

Martin, C.H. 1936. Preliminary report of trap-log studies on elm bark beetles. J. Econ. Ent. 29:297-306.

Meyer, H.J., and D.M. Norris. 1967. Behavioral responses by Scolytus multistriatus (Coleoptera: Scolytidae) to host-(Ulmus) and beetle-associated chemotactic stimuli. Ann. Entomol. Soc. Am. 60:642-647.

Middleton, W., W.D. Buchanan, Curtis May, and J.M. Walter. 1935. Ceratosmella (Graphium) ulmi, the cause of the Dutch elm disease, transmitted by Scolytus multistriatus. J. Econ. Entomol. 28:138.

Neely, D. 1975. Sanitation and Dutch elm disease control, pp. 76-97. In Dutch Elm Disease, Proceedings of the IUFRO Conference, Minneapolis-St. Paul, September 1973. USDA Forest Service Northeastern Forest Experiment Station.

Peacock, J.W., A.C. Lincoln, J.B. Simeone, and R.M. Silverstein. 1971. Attraction of S. multistriatus to a virgin-female-produced pheromone in the field. Ann. Entomol. Soc. Am. 64 (v):1143-1149.

Peacock, J.W. 1975. Research on chemical and biological control of elm bark beetles, pp. 18-49. In Dutch Elm Disease, Proceedings of the IUFRO Conference, Minneapolis-St. Paul, September 1973. USDA Forest Service Northeastern Forest Experiment Station.

Pearce, G.T., W.E. Gore, R.M. Silverstein, J.W. Peacock, R.A. Cuthbert, G.N. Lanier, and J.B. Simeone. 1975. Chemical attractants for the smaller European elm bark beetle, Scolytus multistriatus (Coleoptera: Scolytidae). J. Chem. Ecol. 5:781-793.

Pines, L.L., and A.R. Westwood. 1996. Evaluation of monosodium methane arsenate for the suppression of native elm bark beetles, Hylurgopinus rufipes (Eichhoff) (Coleoptera: Scolytidae). Can. Ent. 128:435-441.

SAS Institute. 1985. User's Guide: Statistics. Version 5 Edition. SAS Institute, Cary, NC. 957 pp.

Stark, W.R., W.E. Waters, and D.L. Wood. 1985. Summary, pp 192-201. In Waters, W.E., R.W. Stark, and D.L. Wood (Eds.). Integrated Pest Management in Pine-Bark Beetle Ecosystems. Wiley and Sons, New York, NY.

Stipes, R.J., and R.J. Campana. 1981. Compendium of Elm Diseases. The American Phytopathological Society, Minneapolis, MN. 96 pp. 
Švihra, P. 1980. Dutch elm disease in California. University of California Cooperative Extension leaflet 21189. $8 \mathrm{pp}$.

Švihra, P., and C.S. Koehler. 1981. Attraction of flying Scolytus multistriatus to cut wood of three elm species in California. Environ. Entomol. 10:565566.

Švihra, P., and C.S. Koehler. 1982. Attack and development of Scolytus multistriatus in smalldiameter elm branches. Environ. Entomol. 11:59a$59 f$.

Švihra, P., and W.J.A. Volney. 1983. Effect of English, Siberian, and Chinese elms on the attack behavior and brood survival of Scolytus multistriatus (Coleoptera: Scolytidae). Can. Ent. 115:513-522.

Welch, D.S. 1953. The Dutch elm disease in urban and forest areas. J. For. 51:641-644.

Wolfenbarger, D.O, and W.D. Buchanan. 1939. Notes on elm twig crotch injuries produced by Scolytus multistriatus Marsham. J. Econ. Entomol. 32: 377-381.

Wood, D.L. 1972. Selection and colonization of ponderosa pine by bark beetles, pp. 101-117. In van Emden, H.F. (Ed.). Insect/Plant Relationships, Symposia of the Royal Entomological Society of London, No. 6, Blackwell Scientific Publications, Oxford, England.

Acknowledgements. I want to acknowledge the help of several persons who contributed significantly to this study: John Parkey, now at Purdue University, with sampling; Dave Docter, formerly arborist with Corporate and Commercial Services, San Jose, who alerted me to the trees in Los Gatos as well as to a tree in Palo Alto, where he is a city arborist; Dr. Carl Koehler, Dr. Theodore Kozlowski, and Dr. David Wood with helpful reviews; and Carol Adams, University of California Statistician, with statistical analysis.

University of California

Cooperative Extension

1682 Novato Blvd., Suite $150 B$

Novato, CA 94549
Résumé. En automne, certains ormes chinois (Ulmus parvifolia Marsham), particulièrement ceux produisant de grandes récoltes de semences, émettent des composés volatiles qui attirent les scolytes Scolytus multistriatus. Les scolytes arrivent en grande quantités sur un seul arbre et tentent sans succès de pénétrer les couches internes de l'écorce. L'arbre répond avec une coulée abondante de sève suivie par une émission de plus fortes quantités de composéshôte attractifs. Les scolytes convergent alors en plus grand nombre encore et forent de très petits tunnels erratiques en surface dans la couche externe de l'écorce. En se basant sur le nombre de tunnels au $\mathrm{dm}^{2}$ de surface, c'est de la base à la mi-hauteur du tronc que l'arbre est le plus densément attaqué. Peut-être en raison de la forte concentration en composés volatiles de l'hôte et d'attractifs produits par l'insecte, les $S$. multistiatus retournent leur attaque contre les ormes avoisinants d'une façon légèrement différente. Les scolytes montrent aussi une préférence pour forer leur trou à mi-hauteur du tronc, mais au coût d'un fort taux de mortalité. Le nombre de scolytes femelles et le nombre de cicatrices d'alimentation laissées dans les fourches des ramilles sont dépendantes en densité: l'accroissement en densité des tunnels est parallèle à celle de l'arrivée des femelles sur les tiges et les branches tout comme à celle de plus de cicatrices d'alimentation sur les ramilles $(P \geq 0,001)$.

Zusammenfassung. Im Herbst verströmen einige Chinesische Ulmen (UImus parvifolia Marsham), besonders die mit großem Samenertrag, flüchtige Substanzen, die Scolytus multistiatus-Käfer anziehen. Die Käfer landen in Massen auf einem Baum und versuchen vergeblich die innere Rinde zu durchbohren. Die Bäume reagieren mit einem enormen Saftfluß, gefolgt von erneutem Ausstoß dieser Substanzen. Die Scolytus-Käfer kommen dann in immer größeren Zahlen auf dem Baum zusammen und bohren sehr kurze und flache Tunnel in die äußere Borke. Basierend auf der Anzahl der Löcher pro $\mathrm{dm}^{2}$ Oberfläche, wurde der untere Stammbereich mit der größten Intensität attakiert. Veilleicht veränderten die S. multistriatus-Käfer ihre Attacken auf die benachbarten Bäume infolge einer hohen Konzentration von Lockstoffen. Die nach Nahrung suchenden Käfer zeigen auch eine Vorliebe, in den mittleren Stammbereich zu bohren, auf Kosten einer hohen Mortalität. Die Anzahl der weiblichen Käfer und die Anzahl der Fraßnarben in den Gabelungen der kleineren Zweige sind abhängig von der Befallsdichte: die Zunahme der Tunneldichte verursachte parallel eine Zunahme der weiblichen Käfer auf dem Stamm und den Ästen und auch mehr Fraßschäden in den Zweigvergabelungen $(P \geq 0.001)$. 
Resumen. En el otoño, algunos árboles de olmo chino (UImus parvifolia Marsham), especialmente aquellos con grandes cosechas de semillas, emiten compuestos volátiles que atraen escarabajos de Scolytus multistriatus. Los escarabajos arriban en masa sobre un árbol solitario e intentan infructuosamente penetrar en la corteza interna. El árbol responde con un copioso flujo de savia seguido de la liberación de más atrayentes producidos por el hospedero. Los escarabajos de Scolytus entonces convergen sobre el árbol en números aún más grandes y excavan túneles muy cortos, erráticos y superficiales en la corteza externa. Con base en el conteo de túneles por dm2 de superficie, la sección de la base a la mitad fue atacada con la densidad más alta.
Quizá debido a la alta concentración de volátiles del hospedero y atrayentes de insectos, los escarabajos de $S$. multistriatus cambiaron su ataque a olmos adyacentes en un patrón ligeramente diferente. Los escarabajos buscadores de comida también muestran una preferencia por barrenar dentro de la sección media, pero a un costo de alta mortalidad. El número de escarabajos hembra y el número de cicatrices por alimentación, dejadas en las horquillas de ramas pequeñas, fueron dependientes de la densidad; el incremento de densidad de túneles fue paralelo al incremento del arribo de hembras al tronco y las ramas, como también a más cicatrices de alimentación en las ramitas $(P \geq 0.001)$. 